\title{
THE BLOOD VOLUMES AND PLASMA PROTEIN DURING LEVARTERENOL-INDUCED HYPERTENSION ${ }^{1}$
}

\author{
BY FRANK A. FINNERTY, JR, ${ }^{2}$ JOACHIM H. BUCHHOLZ, AND \\ ROBERT L. GUILLAUDEU \\ (From the Georgetown University Medical Division, District of Columbia General Hospital, \\ Washington, D. C.)
}

(Submitted for publication August 20, 1957; accepted November 14, 1957)

Studies now in progress in this laboratory suggest that acute reduction of arterial pressure in some hypertensive patients is followed immediately by an increase in plasma volume and a decrease in hematocrit and plasma protein. In order to study this phenomenon further, it seemed worthwhile to perform the reverse experiment, i.e., acute elevation of the arterial pressure.

Levarterenol (Levophed ${ }^{\circledR}$ ) was selected as the pressor agent, first because it produces hemodynamic changes resembling those of hypertension, and second because the arterial pressure could be increased significantly in an asymptomatic fashion.

A review of the literature in reference to the volume of blood and its components after administration of pressor substances is confusing. Prior to 1941, as many investigators found an increase in plasma volume as a decrease (1-4). In 1941, Ebert and Stead (5), and in 1942 Kaltreider, Meneely, and Allen (6), independently found hemoconcentration following epinephrine and explained that the previous discrepancies were due to the fact that other investigators were not allowing time for mixing of dye and plasma prior to the experimental period. At that time, no definite conclusions could be drawn regarding the effect of epinephrine on red cell mass since only indirect methods were available. The evidence suggested, however, that a few red cells were added to the circulation following epinephrine.

It was hoped that the simultaneous measurement

1 This investigation was supported by research grants from: The American Heart Association; The Washington Heart Association, Washington, D. C.; The National Heart Institute (H-2509), National Institutes of Health, Bethesda, Md.; Irwin, Neisler \& Co., Decatur, Ill.; Ciba Pharmaceuticals, Inc., Summit, N. J.; and Charles Pfizer \& Co., Inc., Brooklyn, N. Y.

2 This work was done during the tenure of an Established Investigatorship of the American Heart Association. of plasma volume and red cell mass by direct methods before and during levarterenol infusion would clarify some of the questions regarding the change of the blood volume and its components after pressor substances.

\section{MATERIALS AND METHODS}

Experimental procedures were carried out on $10 \mathrm{pa}-$ tients without obvious cardiovascular disease. Five were female and five were male.

The plasma volume, red cell mass, hematocrit and plasma protein were determined in all patients before and during the hypertensive state produced by levarterenol. The patients were in the fasting state. Following a blank sample, a suspension of the patient's red cells incubated with $\mathrm{Cr}^{\text {sil }}$ and washed three times in standard fashion was injected quantitatively into the antecubital vein (7). Two minutes following this injection, a known amount of T-1824 dye was injected into the same antecubital vein with a different syringe. The precise amount of the dye and isotope delivered was determined by a control in vitro injection. Venous samples were drawn from the opposite arm, without the use of a tourniquet, and collected in tubes containing dried heparin at $10,15,20$ and 25 minutes after the injection of the dye for the determinations of optical density, radioactivity, hematocrit and protein. The optical density of the plasma was measured in a spectrophotometer ${ }^{8}$ at a wave length of $620 \mathrm{~m} \mu$. No corrections were necessary for hemolysis. The radioactivity of the whole blood samples was determined in a scintillation well counter.* The plasma volume and red cell mass were calculated by extrapolating the optical density and radioactivity to the times of injection. The hematocrit was measured in Wintrobe tubes. The plasma protein concentration was determined by the copper sulfate specific gravity method (8).

Immediately following the withdrawal of the $25 \mathrm{~min}$ ute venous sample, an intravenous infusion of diluted levarterenol was started ( $4 \mathrm{ml}$. levarterenol bitartrate diluted in $1,000 \mathrm{ml}$. five per cent dextrose in water). Since pain and anxiety by themselves might further alter the various parameters measured in these experiments, care was taken to keep the acute drug-induced hypertensive state asymptomatic. If the arterial pressure rise

\footnotetext{
3 Coleman Instruments, Inc., Maywood, Ill.

\& Nuclear Instrument and Chemical Corp., Chicago, Ill.
} 
were gradual (i.e., over a 10 to 15 minute period), the mean arterial pressure could be increased by more than 40 per cent without causing untoward symptoms. All arterial pressures were recorded by sphygmomanometer and the mean arterial pressure calculated from the formula (systolic plus diastolic pressure)/2. Once the levarterenol infusion was started, the blood pressure was recorded every minute and the speed of injection regulated to insure an asymptomatic arterial pressure rise. Three additional venous samples were drawn at five minute intervals while the arterial pressure was being acutely increased. When the arterial pressure had stabilized, an additional venous sample was drawn for reference which was immediately followed by a second injection of $\mathrm{Cr}^{\mathrm{s1}}$ labelled red cells and $\mathrm{T}-1824$. A typical experiment is depicted in Figure 1.

\section{RESULTS}

The effect of levarternol on the blood volume and its various components is shown in Table $\mathrm{I}$. An average increase of 56 per cent in mean arterial pressure was associated with an average decrease of 15 per cent in plasma volume ( $p<$ $0.01)$, no change in red cell mass, an average increase of 8 per cent in hematocrit $(p<0.01)$, and an average increase of 5 per cent in plasma protein $(\mathrm{p}=0.05)$.

The protein pool [plasma volume (T-1824) times protein concentration] decreased after the administration of levarterenol from an average of

F.W.
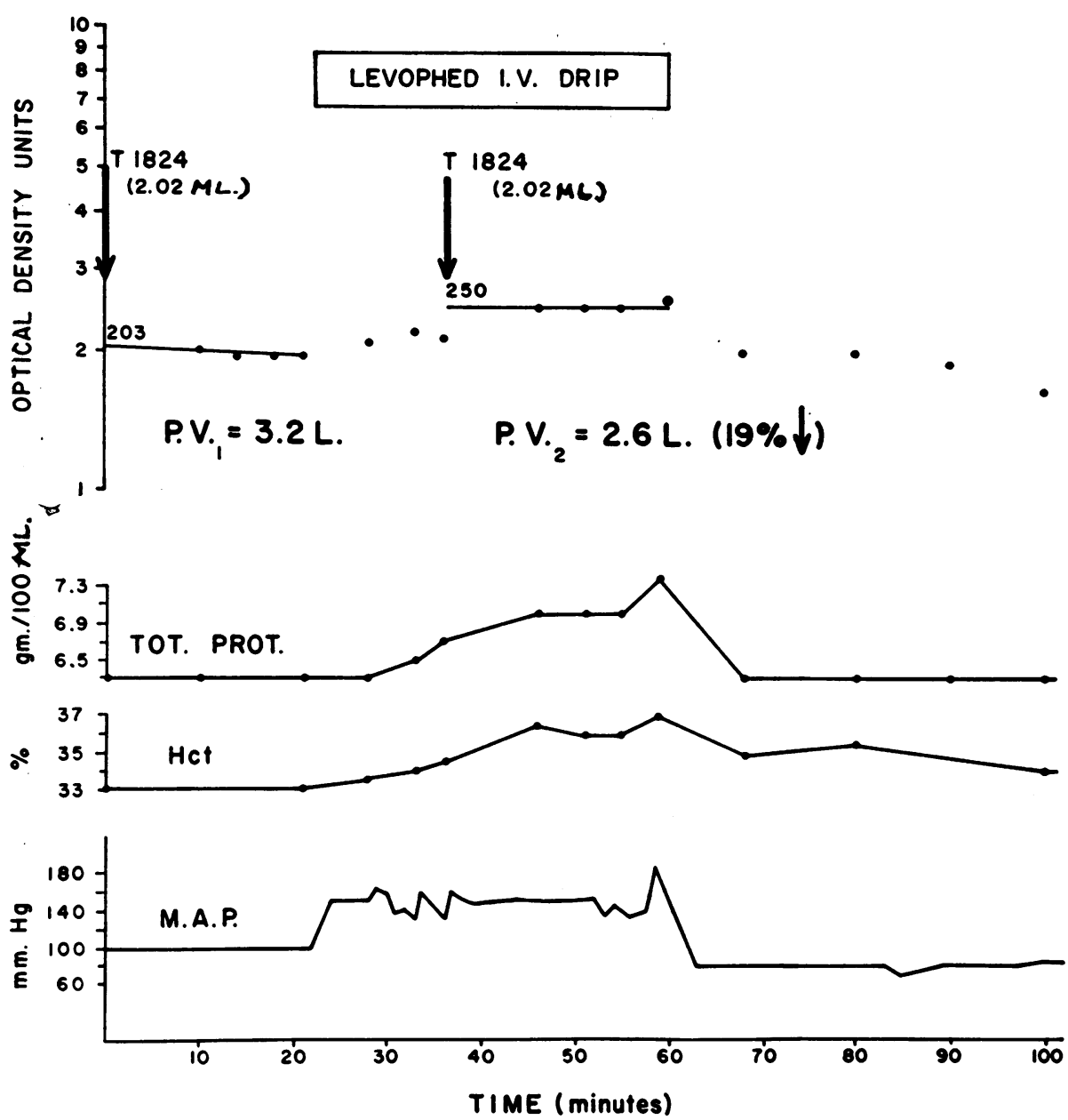

Fig. 1. A Typical Experiment Showing the Effect of Levarterenol on the Arterial Pressure, Hematocrit, Total Protein and Plasma Volume

The red cell mass is not plotted since no change occurred. Note the evidence of hemoconcentration from all parameters and the immediate relationship between changes in arterial pressure and hematocrit, protein and the individual readings of optical density of T-1824. 
215 grams to $193(\mathrm{p}=0.5)$ grams which represents an average loss of 22 grams or 10 per cent of the plasma proteins (Table II).

When the calculation of the protein pool is based on indirect measurements of plasma volume (plasma volume equals (red cell mass/hematocrit) minus red cell mass), levarterenol infusion was accompanied by a decrease in protein pool from an average of 155 grams to 143 grams (12 grams or 8 per cent $)^{5}(p=0.7)$. Although the changes in protein pools are not significant $(p=0.5$, and $p=0.7$ ), it should be noted in Table II that all changes in protein concentrations are in the same direction.

\section{DISCUSSION}

Regardless of the parameter studied, the data suggest that the hypertension induced by levarterenol is associated with hemoconcentration. Compared to control determinations, there is an increase in the percentage of packed red cells, the radioactivity per $\mathrm{ml}$. of whole blood, the optical density of the T-1824 dyed plasma and in the concentration of plasma protein.

Since the plasma proteins in these experiments were measured by the copper sulfate specific gravity method, the effect of changes in the nonprotein constituents of the plasma has to be considered. The studies of Bernstein (9) and Lowry and Hunter (10) have shown that even gross changes of nonprotein constituents do not appreciably alter the protein concentration as measured by specific gravity methods (e.g., each $100 \mathrm{mg}$. per cent increase in glucose causes an increase in the calculated protein of only 0.1 to 0.15 gram per $100 \mathrm{ml}$.). It was concluded, therefore, that the increase in specific gravity of the serum noted in these experiments during levarterenol represents an increase in plasma protein concentration.

It has been shown that epinephrine can cause an increase in the optical density of the nondyed plasma (11). The concomitant increase in hematocrit, concentration of protein and T-1824 in the plasma (Figure 1) during levarterenol indicates that the increase in the optical density of the dyed plasma mainly represents hemoconcentration. This interpretation is further substantiated by work in progress in this laboratory substituting

${ }^{5}$ Calculation of the protein pool was based on only nine patients.

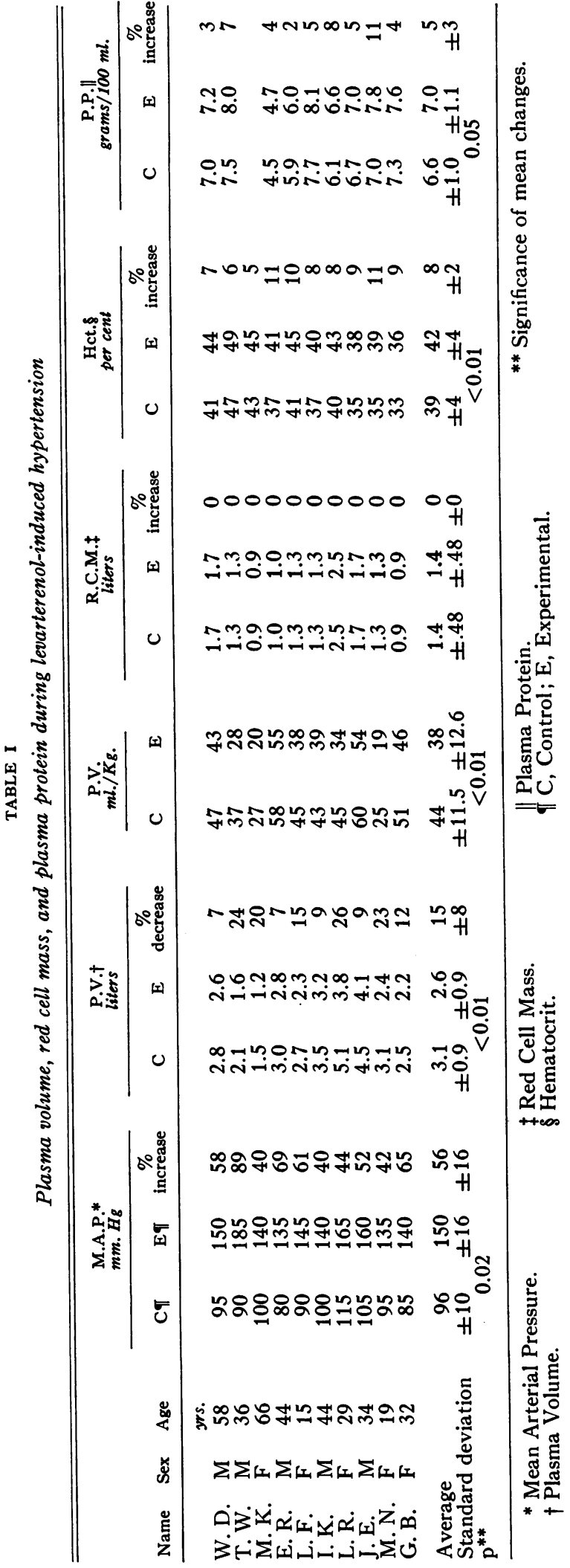




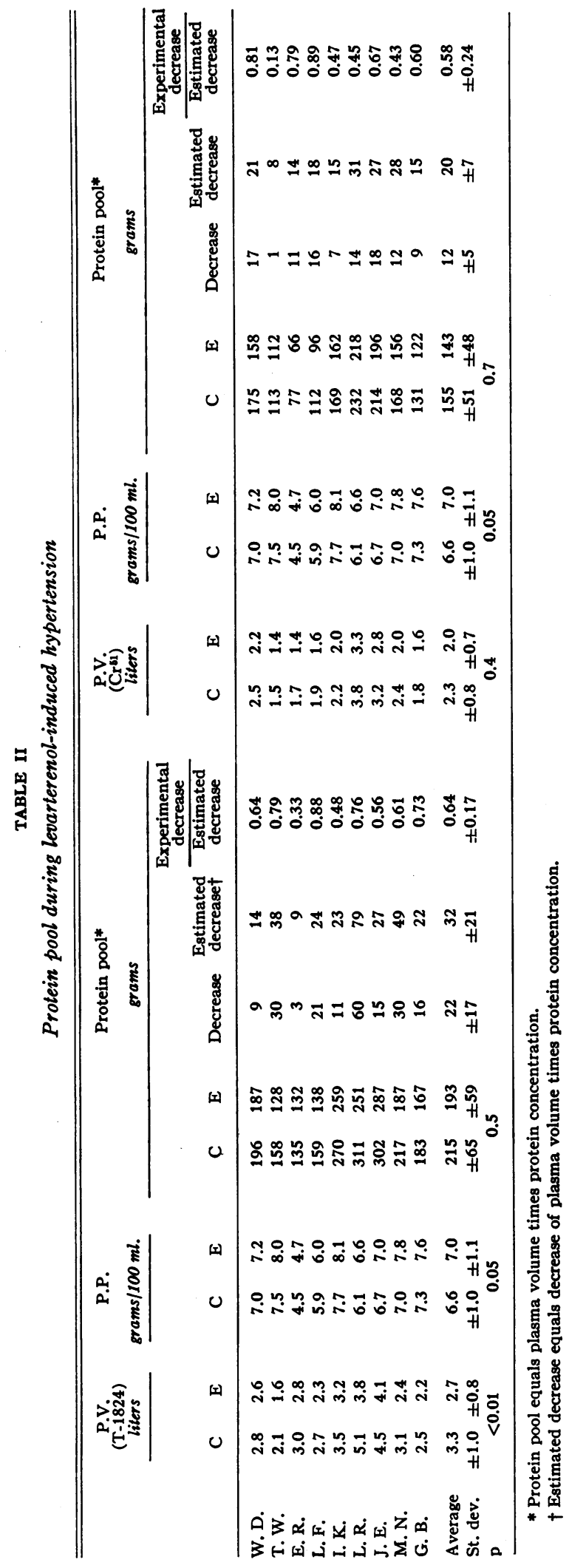

$\mathrm{I}^{131}$ for $\mathrm{T}-1824$ which shows an increase in the radioactivity of the plasma during levarterenol infusion (12).

The data presented here are in accord with those of Ebert and Stead (5) and Kaltreider, Meneely, and Allen (6), who demonstrated hemoconcentration during epinephrine-induced hypertension. Our data point out, however, that red cells are not added to the circulation as these investigators had postulated. The increased radioactivity of the whole blood is completely accounted for by the increased hematocrit.

The close relationship between the change in arterial pressure, hematocrit and plasma protein concentration is evident in Figure 1. It is also clear that these changes are quickly reversed when the levarteranol is discontinued.

Increased hydrostatic capillary pressure seems the most likely explanation for the decrease of plasma volume caused by levarterenol. Goldenberg, Pines, Baldwin, Greene, and Roh (13) and McDowall (14) have shown that levarterenol causes an increase in venous pressure and by inference an increase in hydrostatic capillary pressure. In addition, the generalized elevation of arterial pressure would also tend to increase the hydrostatic pressure. The absence of change in the red cell mass eliminates the possibility of a portion of the circulation being trapped. It would seem that the sequestration of plasma in temporarily closed capillaries (or capillaries with a very slow circulation) is excluded as the sole explanation for hemoconcentration, since an increase in the optical density of the plasma occurs before a second injection of $\mathrm{T}-1824$.

The protein pool is larger when the T-1824 value for the plasma volume is used for calculation than when the indirect chromium method is used. The most likely explanation for this discrepancy lies in the fact that the space measured by the T-1824 is greater than the one simultaneously measured with $\mathrm{Cr}^{51}$.

It is interesting to note that although the magnitude of the protein pool varies with the method used to measure the plasma volume, the decrease during levarterenol infusion is fairly proportional (10 and 8 per cent) (Table II). This proportional decrease is explained by the fact that both the volume of distribution of T-1824 and the de- 
gree of hemoconcentration during levarterenol are greater than when measured by chromium.

The average ratio of protein loss as found in the experiment to the protein loss when calculated from the decrease in plasma volume was 0.64 ( $\mathrm{T}-1824)$, compared to $0.58\left(\mathrm{Cr}^{51}\right)$ (Table II). These data would seem to indicate that the fluid lost from the vascular compartment during levarterenol-induced hemoconcentration contains an average of 64 per cent (T-1824) or 58 per cent $\left(\mathrm{Cr}^{51}\right)$ of the protein concentration of the plasma.

\section{CONCLUSIONS}

1. The hypertensive state produced by levarterenol is associated with an increase in hematocrit and plasma protein, a decrease in plasma volume, and no change in the red cell mass.

2. The fluid lost during hemoconcentration contains less protein than the plasma.

\section{REFERENCES}

1. Wollheim, E. Die zirkulierende Blutmenge und ihre Bedeutung für Kompensation und Dekompensation des Kreislaufs. Z. klin. Med. 1931, 116, 269.

2. Brandt, $F$. Die Abhängigkeit des Venendruckes von der Grösse der zirkulierenden Blutmenge, zugleich ein Beitrag zur Frage seiner klinischen Bedeutung. Z. klin. Med. 1931, 116, 398.

3. Levin, E. La accion de la adrenalina sobre el volumen de la sangre circulante. Rev. méd. Rosario 1935, 25, 255.
4. Hitzenberger, $\mathrm{K}$, and Tuchfeld, $\mathrm{F}$. Utber den Einfluss des Adrenalins auf die zirkulierende Blutmenge. Klin. Wschr. 1929, 8, 1208.

5. Ebert, R. V., and Stead, E. A., Jr. Demonstration that in normal man no reserves of blood are mobilized by exercise, epinephrine, and hemorrhage. Amer. J. med. Sci. 1941, 201, 655.

6. Kaltreider, N. L., Meneely, G. R., and Allen, J. R. The effect of epinephrine on the volume of the blood. J. clin. Invest. 1942, 21, 339.

7. Sterling, K., and Gray, S. J. Determination of the circulating red cell volume in man by radioactive chromium. J. clin. Invest. 1950, 29, 1614.

8. Phillips, R. A., Van Slyke, D. D., Emerson, K., Hamilton, P. B., and Archibald, R. M. The copper sulfate method for measuring specific gravities of whole blood and plasma. Bull. U. S. Army med. Dep. 1943, no. $71,66$.

9. Bernstein, R. E. The relation between plasma specific gravity or water content and plasma protein concentration in normal and abnormal bloods. $\mathrm{S}$. Afr. J. med. Sci. 1954, 19, 131.

10. Lowry, O. H., and Hunter, T. H. The determination of serum protein concentration with a gradient tube. J. biol. Chem. 1945, 159, 465.

11. Ebert, R. V., and Stead, E. A., Jr. An error in measuring changes in plasma volume after exercise. Proc. Soc. exp. Biol. (N.Y.) 1941, 46, 139.

12. Finnerty, F. A., Jr., Buchholz, J. H., and Tuckman, J. Unpublished data.

13. Goldenberg, M., Pines, K. L., Baldwin, E. DeF., Greene, D. G., and Roh, C. E. The hemodynamic response of man to norepinephrine and epinephrine and its relation to the problem of hypertension. Amer. J. Med. 1948, 5, 792.

14. McDowall, R. J. S., Ed. Ciba Foundation Symposium on Visceral Circulation. Boston, Little Brown and Co., 1953. 